\title{
Associated Gas Utilization Using Gas Turbine Engine, Performance Implication-Nigerian Case Study
}

\author{
Nnamdi Anosike1, Abudssalam El-Suleiman², Pericles Pilidis ${ }^{3}$ \\ ${ }^{1}$ Mechanical Engineering Department, Nnamdi Azikiwe University, Awka, Nigeria \\ ${ }^{2}$ Department of Mechanical Engineering Technology, Federal Polytechnic, Nasarawa, Nigeria \\ ${ }^{3}$ Deparment of Power and Propulsion Engineering, Cranfield University, Cranfield, UK \\ Email: nb.anosike@unizik.edu.ng
}

Received 29 January 2016; accepted 13 March 2016; published 16 March 2016

Copyright (C) 2016 by authors and Scientific Research Publishing Inc.

This work is licensed under the Creative Commons Attribution International License (CC BY). http://creativecommons.org/licenses/by/4.0/

(c) (i) Open Access

\section{Abstract}

Typically, crude oil production in Nigeria always accompanied by surface production of associated gas. With little associated gas recovery facilities in place, majority of associated gas is continuously flared with few portions re-injected into the reservoir for enhance oil recovery (EOR). In addition to environmental hazards, wasting substantial amount of produced associated gas is deemed detrimental to a country currently generating less than $54 \%$ of its electric power requirement. Onsite power generation as one of the many means of utilization of associated gas has been conceived. Conversely, the availability and performance of the gas turbine engine for onsite associated gas utilization requires evaluation owing to variations in associated natural gas composition globally and the dependency of associated gas production on reservoirs and oil production activities. This paper presents an analytical investigation of gas turbine engine inspired by GE LMS100 frame engine for onsite utilization of associated gas in Nigeria. Gas turbine performance results are presented and performance parameters are compared against typical commercial natural gas grade.

\section{Keywords}

Associated Gas Monetization, Onsite Power Generation, Gas-to-Power, Gas Turbine Performance

\section{Introduction}

Associated gas reserves are estimated to be about $17 \%$ of global natural gas reserves, with majority of this gas

How to cite this paper: Anosike, N., El-Suleiman, A. and Pilidis, P. (2016) Associated Gas Utilization Using Gas Turbine Engine, Performance Implication-Nigerian Case Study. Energy and Power Engineering, 8, 137-145. 
occurring in small scale [1]. Nigerian associated gas reserve is estimated to be around $60 \%$ of her natural gas reserves [2]. Associated gas flaring is the practice of burning off natural gas during oil production when it comes to the surface facility in places where there are no infrastructures for its utilization and as a precautionary measure. Gas flaring in general is damaging, sum up to energy wastage, increase greenhouse gas emission and is no longer acceptable.

Associated gas flaring in Nigeria began almost six decades ago [3], the era when associated gas was only regarded as unwanted byproduct of oil production. Despite the increasing economic and environmental benefits of associated gas utilization and Nigerian government initiatives/policies to stop flaring, more than $50 \%$ of produced associated gas in Nigeria is still flared to open air. This quantity contributes up to $16 \%$ of global gas flares [4] with a reported 1.2 billion standard cubic feet of flare gas a day (bscf/d). Specifically, in 2014 between January and September alone Nigeria lost about $\$ 1$ billion to gas flaring [5] and since September 2015, surge in associated gas flaring has raised unprecedented concerns within the country. The continuous associated gas flaring practiced in Nigeria has been mainly attributed to lack of gas infrastructures, poor implementation of government policies and local price of gas.

Today, natural gas represents above $15 \%$ of world total energy consumptions [6]. Nigeria having abundant gas resource is still facing power crisis, currently producing about $4500 \mathrm{MW}$ of electricity, which is far below 10,000 MW estimated energy requirement of the country. The situation is more devastating now that existing power plant's availability is reduced up to $15 \%$ due to shortages in gas supply, besides those contributed by inadequate transmission grid capacity. The quantity of gas being flared can improve the gas supply for electricity generation plants which depend on about $85 \%$ - 95\% of gas as a feedstock. The recent deregulation and privatization of electricity generation and distribution in Nigeria have seen growth in new power generation plants. However, most of these power plants are producing below their rated outputs due to shortages in gas supply and transmission difficulties. Recently, a group called Association of Nigerian Electricity Distributors (ANED) claimed about 28 billion naira loss per month as average loss incurred by the power producers (mainly gas-turbine-based power stations). ANED clamored for change to reduce and prevent the losses and criticized the Nigerian Electricity Regulatory Commission (NERC) pricing model. Such losses if not for NERC pricing model, generally from performance point of view can be attributed to power plant protracted part-load operations or plant capacity factor reductions because of gas supply shortages, and inadequate transmission grid capacities, among others.

Exploitation of associated gas for power generation called Gas to Power (GTP) or Gas to Wire (GTW) is envisaged to have the potential of monetizing vast majority of associated gas and stranded natural gas reveres and boost power generation capacity [2] [7]-[9]. Currently, there are monetization projects for utilization and transportation of Nigeria associated gas and natural gas reserves. These include the liquefied natural gas (LNG), gas pipeline (GPL), gas to liquids (GTL), liquefied petroleum gas (LPG) and gas injection project for EOR. The most matured technology in Nigeria is LNG. The Nigerian Liquefied Natural Gas (NLNG) company is playing a bigger role in harnessing natural gas in Nigeria, monetization more than $3000 \mathrm{MMscf} / \mathrm{d}$ of natural gas.

The LNG and most mature monetization technologies relatively require higher amount of associated gas throughput or gas reverses compared to GTP. The amount of natural gas reserves suitable for utilization by GTP projects has been estimated to be within 10 billion cubic feet (Bscf) to 1 trillion cubic feet (Tscf) [10]. On this basis, the GTP or GTW is more attractive monetization option suitable for standalone onsite monetization of associated gas. Though, the performance and availability of the gas turbine will vary with associated gas composition and oil production activities respectively. This paper is set out to investigate the performance and preliminary economic characteristics of onsite monetization of associated gas using gas turbine. This is envisaged to augment the needed distributed power generation, increase energy output, and reduce flaring of associated natural gas while increasing the share of natural gas in Nigerian electricity generation.

\section{Nigerian Primary Energy Consumption}

The share of natural gas as primary energy source in Nigeria based on 2012 statistics is about 6\%, the same year Nigerian total primary energy consumption was estimated around 4.5 quadrillion British thermal unit (Btu) [11]. The traditional burning of solid biomass and waste mainly of wood, charcoal, manure, and crop residues accounted for the highest share of local primary energy consumption, (Figure 1) without 35,000 shorttons of coal consumed in 2012. The consumption of biomass is still mainly domestic based, mainly for cooking and little quantity used in furnaces in local metalworking shops. The conversion of biomass energy in Nigeria to include open fire cooking is inefficient and hazardous. 
Oil, hydro and natural gas have been used to provide electricity in Nigeria. In the last three decades, the annual Nigerian electricity energy consumption has seen an increase from 1273 GWh in 1970 to 29,573 GWh in 2012. This growth is generally seen to be well below the anticipated growth rate, and this is contributed by many factors to include inaccessibility to the national grid, inadequacies of the electricity supply and inefficient private generators. The total installed capacity of inefficient private generators by industries and homes is estimated between $30 \%$ to $50 \%$ of installed capacity of the national grid [12] [13]. Figure 2 presents non-associated and associated natural gas reserves by oil companies in Nigeria [14]. In total associated gas reserve is about $2 \%$ less than non-associated natural gas reserves. The ratio of associated gas to non-associated gas is 0.5 to 3 across the companies listed. This highlights abundant presence of associated gas resource in Nigerian gas reserves.

\section{Gas Turbine Based Power Station}

The gas turbine based power stations provides reduced power plant construction time because is based around standardized and often packaged units, providing quick returns for investors. Again, flexibility of gas turbine engines to run on wide range of fuels coupled with growing number of distributed power generation due to deregulation in electric industries, favors gas turbine engine for power generation. Low carbon content of natural gas compared to other fossil fuels and its availability increased natural gas share as fuel for power generation. Gas turbine based power stations have rapidly increased in Nigeria with 18 new power plants built between 2002 and 2014. Natural gas fired power plants in Nigeria contributed about 28\% more than any other source of installed grid-connected electricity generation Figure 3.

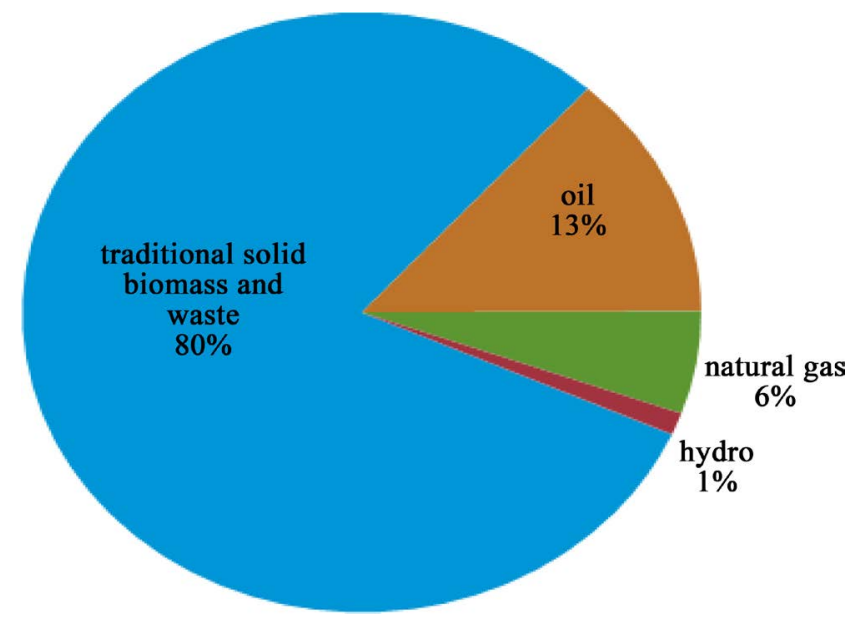

Figure 1. Nigeria’s total primary energy consumption, 2012 [11].

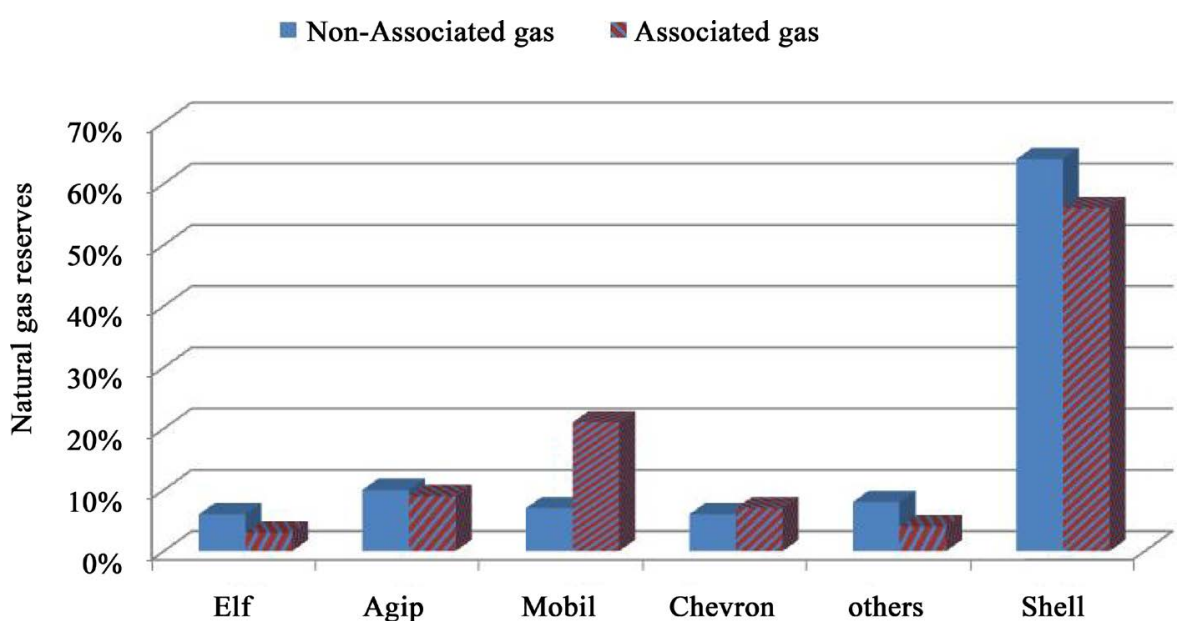

Figure 2. Associated and non-associated natural gas reserves by companies in Nigeria. 


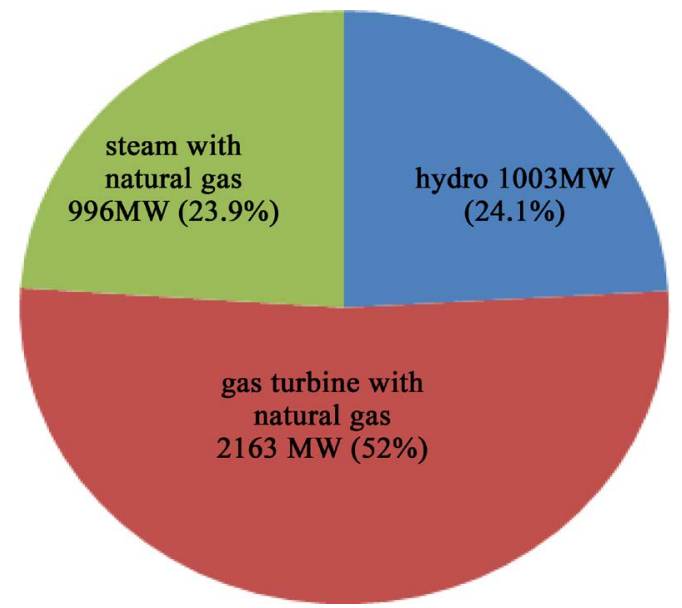

Figure 3. Associated Nigeria's electricity generation by type.

However, unlike diesel and kerosene, performance of gas turbine engine running on associated gas would vary significantly because there are huge varieties of natural gas blends with more than ten constituents globally [15]. A considerable change in gas composition will have a proportional change in calorific or heating value of the gas as well on the performance of gas turbine engine. For instance, specific heat capacity at constant pressure (ср) of combustion products will vary for different associated gas quality unlike other fuels such as diesel and kerosene, which has constant cp since they are refined to a repeatable composition. This cp is required for all gas turbine engine performance calculations whether design point, off design and during engine testing. Running gas turbines with gas of certain reduced heating value has been reported of having the ability of reducing compressor surge margin [16].

Similarly, certain contaminant in gas turbine fuel (associated gas) can lead to degradation and fouling the nozzle guide van and turbine blades [17]. Commonly known impurities in associated gas are hydrogen sulphide $\left(\mathrm{H}_{2} \mathrm{~S}\right)$, carbon dioxide $\left(\mathrm{CO}_{2}\right)$ and water $\left(\mathrm{H}_{2} \mathrm{O}\right)$. Hydrogen sulphide and carbon dioxide are generally classified as acid rain gas due to their corrosiveness. The most concern for the free sulfur and sulfur compound especially $\mathrm{H}_{2} \mathrm{~S}$ is that sulfur oxidizes during combustion forming $\mathrm{SO}_{2}$ and then acids which are very corrosive. Water can be available either as free water or moisture having corrosive effect and danger of forming ice.

\section{Materials and Method}

\subsection{Associated Gas Composition}

A typical Nigerian associated gas composition shown in Table 1 (lean associated natural gas) was used as gas turbine fuel in this study. The NSA Chemical Equilibrium with Applications (CEA) computer program offered by Gas Turb Detail 5 [18] was used to create gas turbine fuel input file. Lean natural gas is defined by [19], as natural gas that contains a few or no liquefiable liquid hydrocarbons. The low heating value (LHV) for the associated natural from CEA simulation results was found to $46.97 \mathrm{MJ} / \mathrm{kg}$. The NLNG associated gas here represents certain level of processing compared to the sample from Nigerian Agip Oil Company (NAOC) chemical laboratory.

\subsection{Gas Turbine Layout for This Study}

The engine for this study is inspired by GE LMS100 gas turbine depicted in Figure 4. This gas turbine engine is a three spool with intercooler configuration. The intercooler between low pressure compressor (LPC) and high pressure compressor (HPC), reduces the compression work for HPC and allow for high pressure ratio to be achieved with improved all thermal efficiency.

The technical data from GE [21] used as part of modeling and simulation of the engine in this study is shown in Table 2. The modeling and simulation of the gas turbine engine was carried out with GasTurb 11 commercial software for design point and off design performance simulation of gas turbines. The GasTurb model layout of the engine in this study is shown in Figure 5. The design point performance of the GasTurb version of the 
Table 1. Typical composition of Nigeria's associated gas.

\begin{tabular}{ccc}
\hline Constituents & ${ }^{\mathrm{a}} \mathrm{NAOC}$ & ${ }^{\mathrm{b}} \mathrm{NLNG}$ \\
\hline Methane, $\mathrm{CH}_{4}$ & 78.81 & 0.88748 \\
Ethane, $\mathrm{C}_{2} \mathrm{H}_{6}$ & 10.46 & 0.04402 \\
Propane, $\mathrm{C}_{3} \mathrm{H}_{8}$ & 4.62 & 0.02572 \\
Iso-Butane, $\mathrm{C}_{4} \mathrm{H}_{10}$ & 0.79 & 0.00553 \\
$\mathrm{~N}-$ Butane, $\mathrm{C}_{4} \mathrm{H}_{10}$ & 0.97 & 0.00843 \\
Iso-Pentane, $\mathrm{C}_{5} \mathrm{H}_{12}$ & 0.31 & 0.00265 \\
N-Pentane, $\mathrm{C}_{5} \mathrm{H}_{12}$ & 0.27 & 0.00195 \\
N-Hexane, $\mathrm{C}_{6} \mathrm{H}_{14}$ & 0.21 & 0.00174 \\
N-Heptane+, $\mathrm{C}_{7} \mathrm{H}_{16}$ & 0.1 & 0.00178 \\
Carbon Dioxide, $\mathrm{CO}_{2}$ & 2.59 & 0.01957 \\
Nitrogen, $\mathrm{N}_{2}$ & 0.61 & 0.00113 \\
Water, $\mathrm{H}_{2} \mathrm{O}$ & 0.26 & 0.00000 \\
Hydrogen Sulphide, $\mathrm{H}_{2} \mathrm{~S}$ & 0.001 & 0.00000 \\
\hline
\end{tabular}

${ }^{\mathrm{a}}$ Raw associated gas composition in volume percentage: Nigerian Agip Oil Company (NAOC) Chemical Laboratory, 2001; 'bean (dry) associated natural gas in mole fraction: Nigeria Liquefied Natural Gas (NLNG) Company data.

Table 2. Some of the design point performance data based on natural gas $(50 \mathrm{~Hz})$.

\begin{tabular}{cccc}
\hline \multirow{2}{*}{ Engine parameter } & \multicolumn{2}{c}{ OEM [20] } & This study \\
\cline { 2 - 3 } & SAC & DLE $^{\mathrm{b}}$ & \\
\hline Power output $(\mathrm{MW})$ & 113.4 & 102 & 102 \\
Heat rate LHV $(\mathrm{kJ} / \mathrm{kW}$-hr) & 8291 & 7816 & 7818 \\
Pressure ratio (-) & $43: 1$ & $43: 1$ & $43: 1$ \\
Exhaust flow $(\mathrm{kg} / \mathrm{sec})$ & 235 & 224 & 294 \\
Exhaust temperature $\left({ }^{\circ} \mathrm{C}\right)$ & 414 & 409 & 476 \\
Power turbine speed (rpm) & 3000 & 3000 & 3000 \\
Fuel LHV $(\mathrm{MJ} / \mathrm{kg})$ & 44.194 & 44.194 & 49.737 \\
Net efficiency (\%) & 46 & 46 & 46 \\
Intlet mass flow $(\mathrm{kg} / \mathrm{s})$ & 235 & 235 & 235 \\
Firing temperature, TET $\left({ }^{\circ} \mathrm{C}\right)$ & 1380 & 1380 & 1380 \\
Ambient $\left({ }^{\circ} \mathrm{C}\right)$ & 15 & 15 & 15 \\
Relative humidity $(\%)$ & 60 & 60 & 60 \\
\hline
\end{tabular}

${ }^{\mathrm{a} S A C}$ : Single Annular Combustor; ${ }^{\mathrm{b}} \mathrm{DLE}$ : Dry Low Emissiom Combustor.

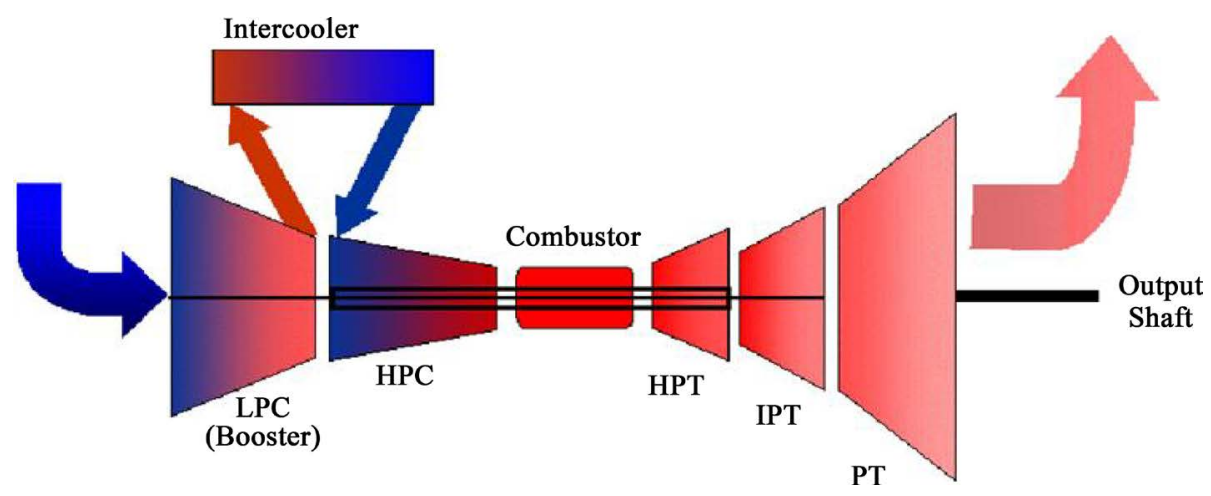

Figure 4. LMS100 gas turbine configuration [20]. 
engine was validated with available data from Table 2. The design point performance results for modeled engine are arguably the same with the original equipment manufacturer's (OEM’s) dry low emission (DLE) combustor. One of the primary reasons there is a slight variation in the performance parameters could be as a result of variation in natural gas qualities for this simulation and OEM test. The off-design simulation of the gas turbine considered the typical Nigerian ambient temperature $\left(18^{\circ} \mathrm{C}\right.$ to $\left.45^{\circ} \mathrm{C}\right)$.

\subsection{Design and Off-Design Point Performance}

The design point (DP) performance analysis compares the DP performance parameters of the gas turbine engine running with associated gas and a known commercial quality natural gas, Table 3 at standard conditions. The standard ambient conditions were $60 \%$ relative humidity, $15^{\circ} \mathrm{C}$ inlet temperature and pressure of $101.325 \mathrm{kPa}$. Some parameters showed more variations in design point simulation value from commercial natural gas quality to associated gas. These parameters were considered in the engine handle for off-design performance simulation.

The off-design (OD) point performance analysis was done to evaluate the performance of the engine in typical Nigerian ambient temperature profile. This is of most interest for this study as impact of increase in ambient temperature drastically affects gas turbine inlet air, performance and increase specific cost of power produced. Similarly, other OD point performance as a function ambient temperature profile evaluated were, power variation, part-power efficiency, compressor surge margin, gas turbine grid frequency variation, $\mathrm{NO}_{\mathrm{x}}$ emission due

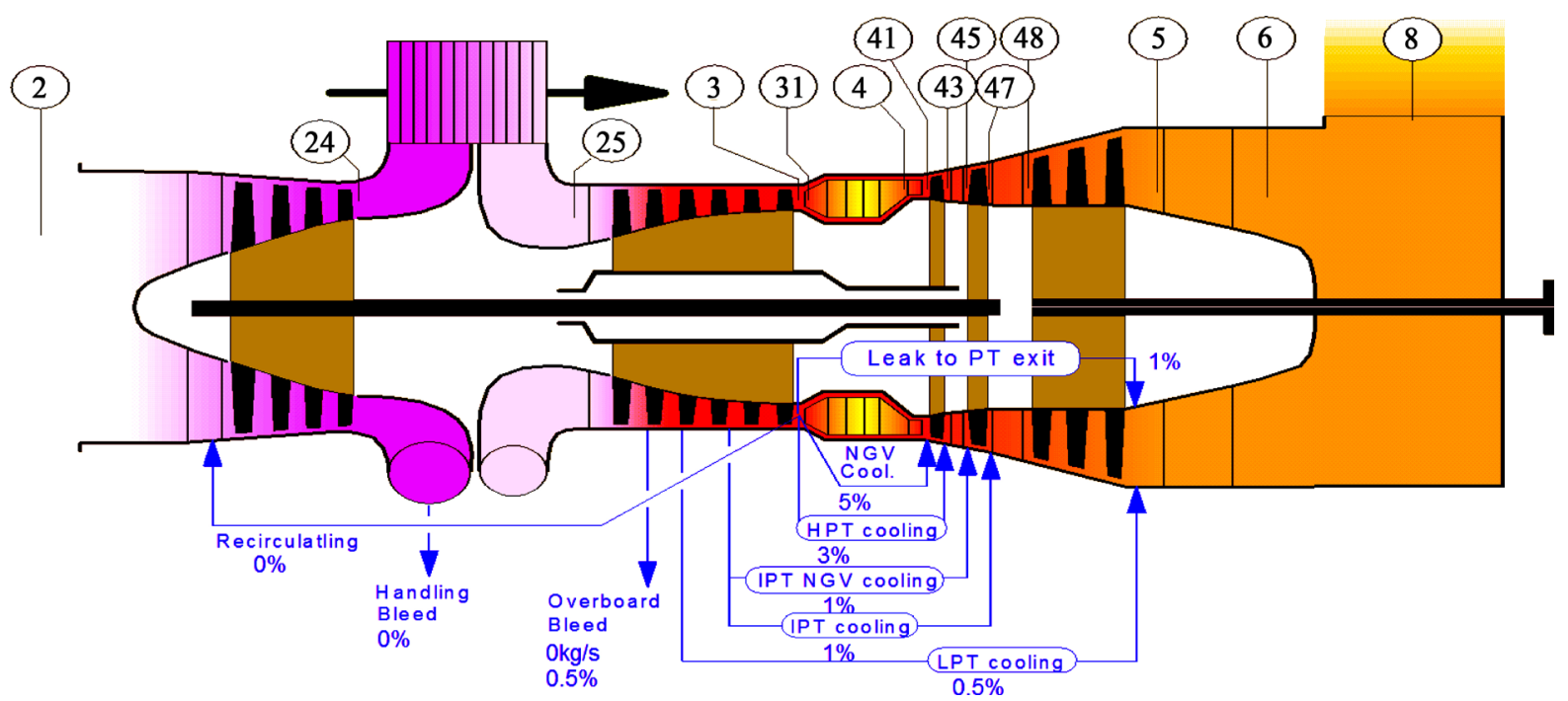

Figure 5. GasTurb 11 model layout of the gas turbine engine for this study.

Table 3. Model engine design point performance parameters on associated gas and commercial quality gas.

\begin{tabular}{ccc}
\hline Design point parameter & \multicolumn{2}{c}{ Modeled engine running on fuel } \\
\cline { 2 - 2 } Shaft power $(\mathrm{kW})$ & Natural gas & Associated natural gas \\
\cline { 2 - 2 } Power SFC $\left(\mathrm{kg} / \mathrm{kW}{ }^{*} \mathrm{~h}\right)$ & $101,963.0$ & $101,997.4$ \\
Heat rate $(\mathrm{kJ} / \mathrm{kW}$ ) & 0.1572 & 0.1665 \\
Fuel flow $(\mathrm{kg} / \mathrm{s})$ & 7817.9 & 7819.9 \\
$\mathrm{NO}_{\mathrm{x}}$ severity $($ factor$)$ & 4.45201 & 4.71692 \\
Thermal efficiency, (fraction) & 3.35327 & 3.35327 \\
Exhaust gas tempertarate $\left({ }^{\circ} \mathrm{C}\right)$ & 0.46048 & 0.46037 \\
Exhaust gas flow rate $(\mathrm{kg} / \mathrm{s})$ & 475.75 & 475.63 \\
PT nominal speed $(\mathrm{rpm})$ & 293.592 & 293.717 \\
Turbine entry temperature, $\mathrm{TET}\left({ }^{\circ} \mathrm{C}\right)$ & 3000 & 3000 \\
\hline
\end{tabular}


high firing temperature, power, heat rate fuel flow and specific fuel consumption, thermal efficiency, $\mathrm{NO}_{\mathrm{x}}$ severity factor and exhaust gas quality. Some of these quantities are compared and analyzed between associated gas and commercial quality natural gas.

\section{Results and Discussion}

The OD point performance results of the modeled gas turbine engine, running on the associated gas sample and commercial quality natural gas of $49.74 \mathrm{MJ} / \mathrm{kg} \mathrm{LHV}$ were compared and presented below. Changing fuel from natural gas to associated gas, the output power and thermal efficiency for gas turbine inlet temperatures between $18^{\circ} \mathrm{C}$ and $45^{\circ} \mathrm{C}$ showed slight variations in both performance parameters, Figure 6. More changes were observed in shaft power than thermal efficiency.

Figure 7 shows the shaft power specific fuel consumption variation with the ambient temperature profile for both fuels. While the variation in thermal efficient is considerably small between natural gas and associated gas, there is about $5.6 \%$ increase in fuel consumption $(\mathrm{kg} / \mathrm{kWh})$ for every $1^{\circ} \mathrm{C}$ increase inlet temperature for running associated gas. Running the gas turbine for exact power will require more associated gas than natural gas, in the range of $5.5 \%-5.6 \%$ for the ambient temperature $\left(18^{\circ} \mathrm{C}-45^{\circ} \mathrm{C}\right)$ considered.

Changing gas turbine fuel from natural gas to associated gas show very little change in the booster

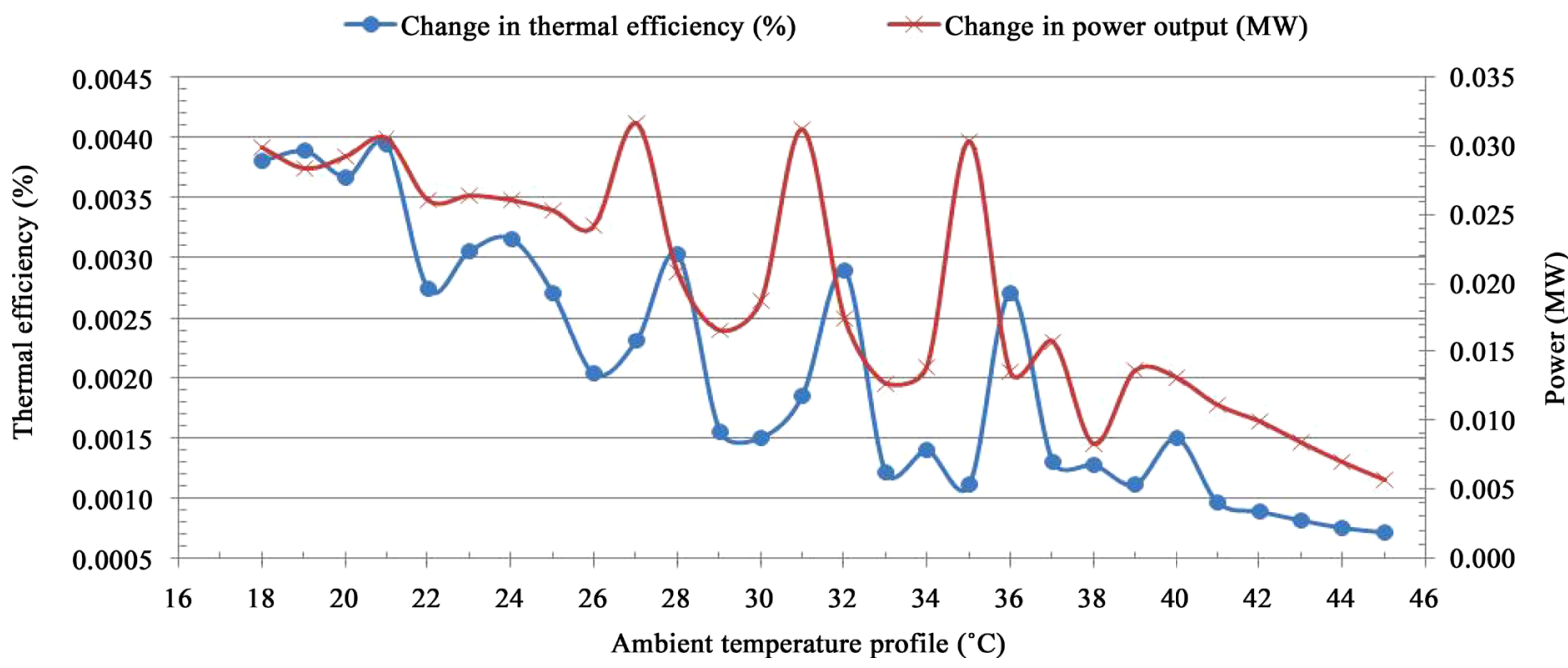

Figure 6. Changes in thermal efficiency and output power due to change of gas turbine fuel.

- Power Sp. Fuel Cons., $\mathrm{kg} /\left(\mathrm{kW}^{*} \mathrm{~h}\right)$

- Fuel Flow, kg/s (NG) $\rightarrow$ Power Sp. Fuel Cons., kg/(kW*h)

$\leftarrow$ Fuel Flow, kg/s (APG)

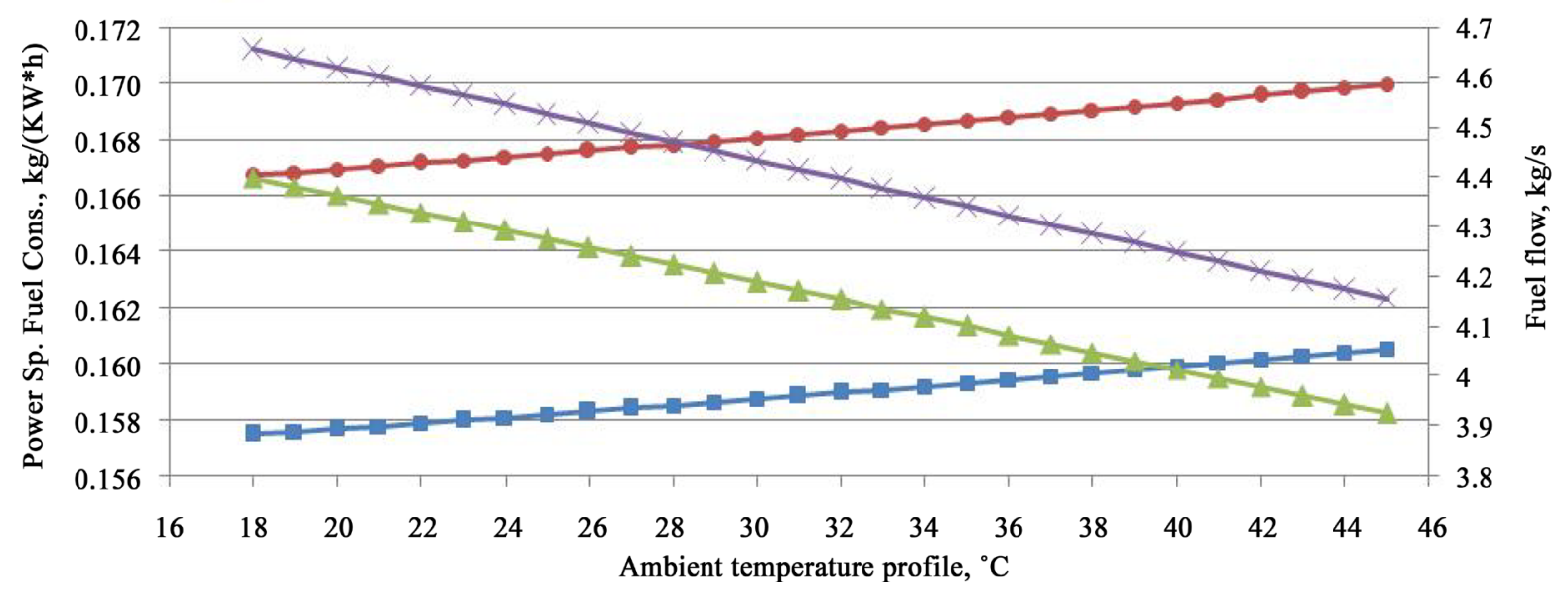

Figure 7. Shaft power specific fuel consumption and fuel flow within ambient temperature profile. 
compressor surge margin with maximum value of $0.018 \%$ Figure 8 . The high pressure compressor (HPC) surge margin showed up to $60.23 \%$ increase. However, following the design parameters for the modeled engine, the compressors (booster and HPC) operating point for both fuels was well within normal surge margin line.

The off-frequency operation without significant power loss as required to support grid system is the same for the modeled engine running on associated gas or non-associated gas Figure 9. The reduction in power output for $1 \%(49.5 \mathrm{~Hz})$ grid frequency deviation is well within less than $1 \%$ output power change. Similarly, variation in grid frequency $5 \%(47 \mathrm{~Hz})$ produces well below $5 \%$ change in gas turbine output power for both fuel scenarios.

\section{Conclusions}

1) Changing gas turbine engine fuel from natural gas to typical Nigerian associated gas considered here had no significant change in thermal efficiency and output power. However, to produce exactly the same amount of power, more volume of associated gas will be consumed. The associated gas has lower heating value than the commercial natural gas grade considered in this study.

2) Performance result shows that gas turbine engines like GE LMS100 will be a very good gas turbine option for standalone onsite associated gas monetization in Nigeria. In addition, this gas turbine engine gives around $41 \%$ to $46 \%$ thermal efficiency within $50 \%$ to $100 \%$ power level [20]. This will be of high advantage considering associated gas production decline regimes.

3) In general, reduction in heating value of fuel reduces the compressor surge margine; however, reduction in compressor (both LP and HP) surge margin due to the reduced heating value of associated gas in this study is insignificant.

4) Gas to power monetization of Nigerian abundant associated gas reserves will boost power generation and reduce flaring in Nigeria while increasing natural gas energy share.

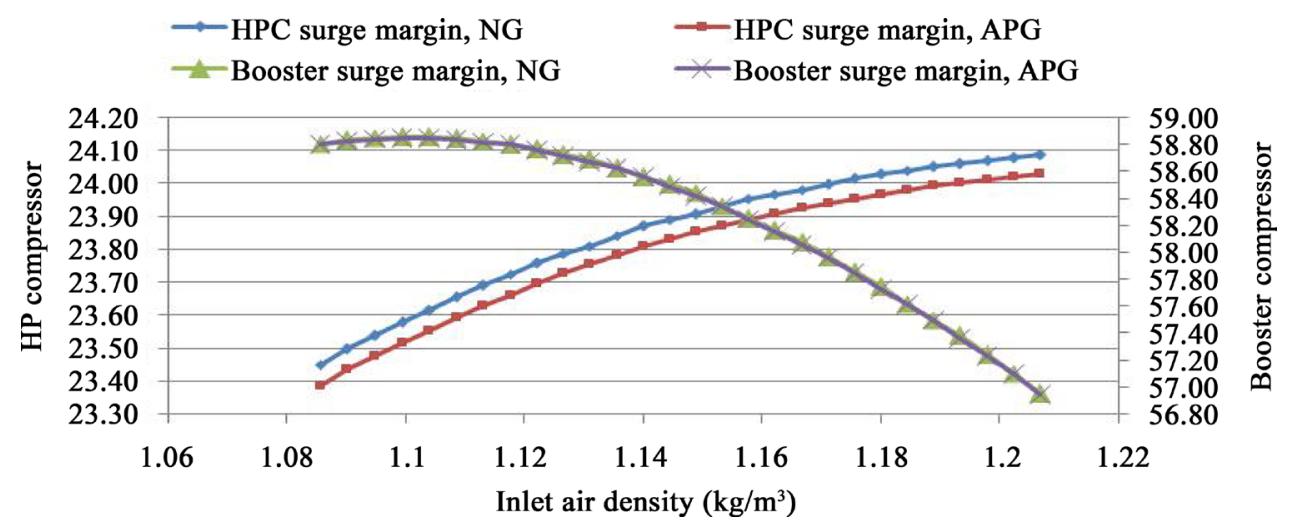

Figure 8. Impact of different fuels on compressors surge margin.

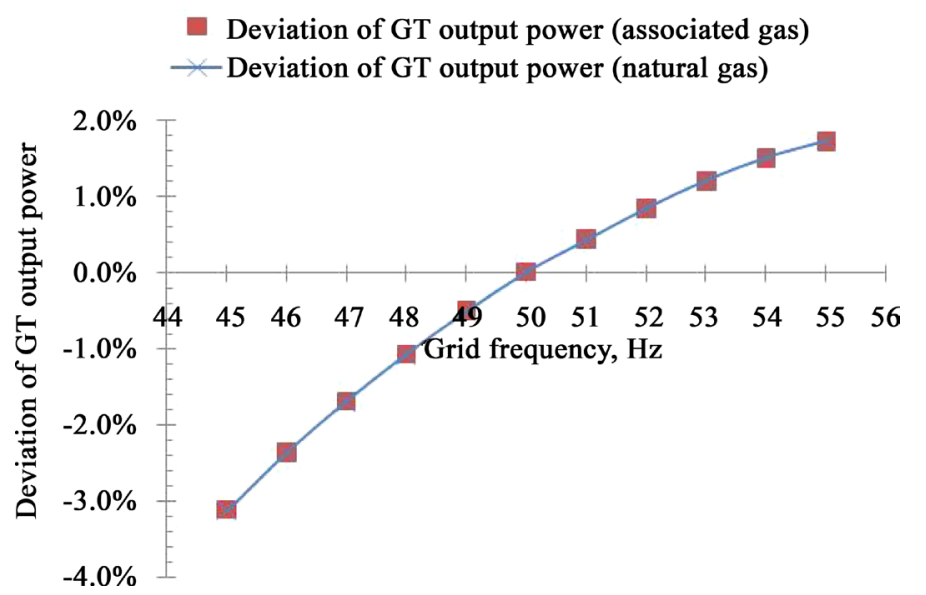

Figure 9. Gas turbine output power deviation and grid frequency variation. 


\section{Acknowledgements}

Petroleum Trust Development Fund (PTDF), Nigeria is highly appreciated for their support at the course of this research to utilize associated gas to power generation and reduce associated natural gas flaring.

\section{References}

[1] Khalilpour, R. and Karimi, I.A. (2009) Evaluation of LNG, CNG, GTL and NGH for Monetization of Stranded Associated Gas with the Incentive of Carbon Credit. International Petroleum Technology Conference, Doha, 5-7 December 2009. http://dx.doi.org/10.2523/IPTC-14083-MS

[2] Adegoke, A., Barrufet, M. and Ehlig-Economides, C. (2005) GTL plus Power Generation: The Optimal Alternative for Natural Gas Exploitation in Nigeria. International Petroleum Technology Conference, Doha, 21-23 November 2005. http://dx.doi.org/10.2523/iptc-10523-ms

[3] Ndubusi, E.N. and Amanetu, M.C. (2003) The Emerging Role of Natural Gas on the African Economy: The Case Study of the Nigerian Gas Industry. Canadian International Petroleum Conference, Cagary, 10-12 June 2003. http://dx.doi.org/10.2118/2003-003

[4] Akachidike, K. (2008) Remote Stranded Gas-Challenges and Opportunities for Development. Proceedings of the 38th Annual Conference of NSChE, Effurun, 30 October-1 November 2008, 3.

[5] George-Adagbo, T. (2015) Shell Set to End Gas Flaring. https://www.today.ng/news/23566/shell-set-to-end-gas-flaring

[6] International Energy Agency (IEA) (2014) Key World Energy Statistics, IEA Paris. www.iea.org

[7] Sonibare, J. and Akeredolu, F. (2006) Natural Gas Domestic Market Development for Total Elimination of Routine Flares in Nigeria’s Upstream Petroleum Operations. Energy Policy, 34, 743-753. http://dx.doi.org/10.1016/j.enpol.2004.07.006

[8] Thomas, S. and Dawe, R.A. (2003) Review of Ways to Transport Natural Gas Energy from Countries Which Do Not Need the Gas for Domestic Use. Energy, 28, 1461-1477. http://dx.doi.org/10.1016/S0360-5442(03)00124-5

[9] Watanabe, T., Inoue, H., Horitsugi, M. and Oya, S. (2006) Gas to Wire System (GTW) for Developing Small Gas Field and Exploiting Associated Gas. International Oil \& Gas Conference and Exhibition in China, Beijing, 5-7 December 2006. http://dx.doi.org/10.2118/103746-ms

[10] Rajnauth, J., Ayeni, K. and Barrufet, M. (2008) Gas Transportation: Present and Future. CIPC/SPE Gas Technology Symposium Joint Conference, Calgary, 16-19 June 2008. http://dx.doi.org/10.2118/114935-ms

[11] The U.S. Energy Information Administration (EIA). http://www.eia.gov/beta/international/analysis.cfm?iso=NGA

[12] Harvard, Program on the Global Demography of Aging (2010) Nigeria: The Next Generation Report, PGDA Working Paper No. 62, 47.

[13] Federal Republic of Nigeria National Energy Policy (2003) www.energy.gov.ng/index.php

[14] Mike, O. (2007) Nigeria Gas Issues. PTDF Gas Research Group University of Port-Harcourt. http://www.beg.utexas.edu/energyecon/abuja_07_workshop/NIGERIA\%20GAS\%20ISSUES\%20(Prof.\%20Onyekonw u).pdf

[15] Walsh, P.P. and Fletcher, P. (2004) Gas Turbine Performance. 2nd Edition, Blackwell, Oxford. http://dx.doi.org/10.1002/9780470774533

[16] Anosike, N.B. (2013) Technoeconomic Evaluation of Flared Natural Gas Reduction and Energy Recovery Using Gasto-Wire Scheme. Ph.D. Thesis, Cranfiled University, Cranfield.

[17] Lefebvre, A.H., Ballal, D.R. and Bahr, D.W. (2010) Gas Turbine Combustion: Alternative Fuels and Emissions. CRC Press, Boca Raton. http://dx.doi.org/10.1201/9781420086058

[18] The GasTurb Program. www.gasturb.de

[19] Schlumberger Oilfield Glossary. http://www.glossary.oilfield.slb.com/en/Terms/l/lean_gas.aspx

[20] General Electric LMS100 Flexible Power. http://cfaspower.com/LMS100_Brochure.pdf

[21] Reale, M.J. (2004) New High Efficiency Simple Cycle Gas Turbine-GE’s LMS100M. GE Energy GER-4222A $(06 / 04)$. 